\title{
An enhanced calibration of a recently released megatree for the analysis of phylogenetic diversity
}

\author{
M. Gastauer ${ }^{a, b} *$ and J. A. A. Meira-Neto ${ }^{a, b}$ \\ a'Laboratório de Ecologia e Evolução de Plantas, Departamento de Biologia Vegetal, Universidade Federal de \\ Viçosa - UFV, Campus UFV, s/n, CEP 36570-000, Viçosa, MG, Brazil \\ ${ }^{b}$ Centro de Ciências Ambientais Floresta-Escola - FLORESC, Av. Prof. Mário Palmeiro, 1000, \\ CEP 38200-000, Frutal, MG, Brazil \\ *e-mail: markus.gastauer@ufv.br
}

Received: October 2, 2014 - Accepted: March 31, 2015 - Distributed: August 31, 2016

(With 2 figures)

\begin{abstract}
Dated or calibrated phylogenetic trees, in which branch lengths correspond to evolutionary divergence times between nodes, are important requirements for computing measures of phylogenetic diversity or phylogenetic community structure. The increasing knowledge about the diversification and evolutionary divergence times of vascular plants requires a revision of the age estimates used for the calibration of phylogenetic trees by the bladj algorithm of the Phylocom 4.2 package. Comparing the recently released megatree R20120829.new with two calibrated vascular plant phylogenies provided in the literature, we found 242 corresponding nodes. We modified the megatree (R20120829mod. new), inserting names for all corresponding nodes. Furthermore, we provide files containing age estimates from both sources for the updated calibration of R20120829mod.new. Applying these files consistently in analyses of phylogenetic community structure or diversity serves to avoid erroneous measures and ecological misinterpretation.
\end{abstract}

Keywords: R20120829.new, phylogenetic community analysis, ecological misinterpretation, phylogenetic diversity, evolutionary divergence times, phylogenetic dispersion, phylogeny of vascular plants.

\section{Calibração aperfeiçoada de uma megatree lançada recentemente para a análise da diversidade filogenética}

\begin{abstract}
Resumo
Árvores filogenéticas datadas, ou calibradas, em que os comprimentos dos ramos correspondem ao tempo evolutivo de divergência entre os nós, são importantes requisitos para calcular medidas de diversidade filogenética ou de estrutura filogenética de comunidades. O conhecimento crescente sobre a diversificação e sobre o tempo de divergência evolutiva das plantas vasculares fez necessária uma revisão das estimativas de idades dos nós que são utilizadas para a calibração de árvores filogenéticas por meio do algoritmo bladj do pacote Phylocom 4.2. Comparando a mega-árvore R20120829.new, recentemente publicada, e outras duas filogenias calibradas de plantas vasculares, encontramos 242 nós correspondentes. Modificamos esta mega-árvore (R20120829mod.new), inserindo todos os nomes dos nós correspondentes. Além disso, providenciamos dois arquivos com todas as estimativas das idades para uma calibração mais atualizada. Utilizando esses arquivos de maneira consistente nas análises de diversidade ou de estrutura filogenética de comunidades, evita-se incorreções nas datações e imprecisões na interpretação de informações ecológicas.
\end{abstract}

Palavras-chave: R20120829.new, análise filogenética de comunidades, má interpretação ecológica, diversidade filogenética, tempo de divergência evolutiva, dispersão filogenética, filogenia de plantas vasculares.

\section{Introduction}

Dated or calibrated phylogenetic trees, in which branch lengths correspond to evolutionary divergence times, are important requirements for computing measures of phylogenetic diversity (Faith, 1992) or phylogenetic community structure (Webb et al., 2002; Gastauer and Meira-Neto, 2014). The importance of correct calibration has been highlighted to avoid ecological misinterpretation,

i.e., the outcome of a correctly calibrated tree indicates a phylogenetic community structure different from the outcome of a wrongly calibrated tree (Gastauer and Meira-Neto, 2013), but achieving an updated calibration is still not an easy task. Furthermore, constantly increasing knowledge about the phylogenetic relationships among vascular plants, especially angiosperms (Smith et al., 2011), and about the 
diversification times of different clades (i.e., Magallón and Castillo, 2009; Lemaire et al., 2011; Magallón et al., 2013) require regular revisions of the database used to achieve updated tree calibrations.

The rapid increase in information results in the periodic release of new, updated megatrees, i.e., phylogenetic hypotheses containing all euphyllophyte families (GitHub, 2014). For phylogenetic community analyses or the computation of phylogenetic diversity measures, these megatrees may be pruned down to a user-supplied list of species by the phylomatic function of the Phylocom 4.2 package (Webb and Donoghue, 2005). By this procedure, all species are inserted as terminals, and branches of the megatree without terminals are cut. Internal node names are maintained. For the calibration of such community trees, the bladj algorithm from the Phylocom package is run (Webb et al., 2008). This algorithm recognizes the names of internal nodes and dates them according to clade dating information provided in a separate ages file. Not matched internal nodes are smoothed by mean dates between fixed divergence times.

The Phylocom package includes the wikstrom.ages file, which provides the minimum age estimates for 176 internal nodes within the angiosperms proposed by Wikström et al. (2001). Revised age estimates are available (e.g. Bell et al., 2010), but still not incorporated within the Phylocom package.

Therefore, the aim of this note is to outline how community trees derived from the megatree R20120829. new, recently released for phylogenetic community analysis and the computation of phylogenetic diversity among vascular plants, are calibrated in the most updated way. For that, we identified and provided recent age estimates from literature of a maximum number of internal nodes that are distributed over the entire megatree.

\section{Material and Methods}

We compared the topology of R20120829.new with two comprehensive revisions about vascular plant diversification (Hedges and Kumar, 2009; Bell et al., 2010). Corresponding nodes, i.e., nodes with the same descending clades or taxa, were identified. If not already named by the authors of R20120829.new, these corresponding nodes were named within the plain text archive of the megatree.

Age estimates from both revisions were pooled to provide updated ages files for tree calibration. In several cases, two or three subsequent nodes within the same lineage were estimated to identical ages by literature. In these cases, the bladj algorithm calibrates the node that appears first in the ages file and ignores age estimates for the other node(s), smoothing by mean dates between fixed divergence times. This causes distortions of the tree altering patterns of phylogenetic diversity, because the subsequent node(s) is/are always fixed to more recent divergence times than hypothetically assumed by literature. To avoid that, we corrected the age estimates of the most recent node of the sequence by $-0.1 \mathrm{Myr}$, while in case of three subsequent nodes with identical age estimations, the oldest one is corrected by $+0.1 \mathrm{Myr}$. Due to this procedure, the topology of R20120829.new is conserved.

To illustrate advances in tree calibration, age estimates of these corresponding nodes were used to calibrate a hypothetic community phylogeny that contains two species from each monophyletic family from R20120829.new. Resulting trees are visualized with FigTree v1.4.2.

\section{Results and Discussion}

Bell et al. (2010) revised Wikstrom's age estimates by dating an angiosperm phylogeny using a relaxed molecular clock calibrated by 36 fossils considered as minimum ages of the most recent common ancestor. They used two slightly different approaches to estimate node ages, one in which they included these minimum age constraints from fossil data into an exponential distribution (BEAST ${ }^{\mathrm{a}}$ analysis in the paper's terminology) and one in which they used a lognormal distribution $\left(\mathrm{BEAST}^{\mathrm{b}}\right)$, two different ages files are provided. This results in two sets of calibration points labeled as ages_exp and ages_logn available from the authors in the Supplementary Material*; either of them might be used to arrive at a revised calibration of the angiosperm clade in a user-specific community tree, given the user is aware of the possible shortcomings and pitfalls of both types of approaches. Furthermore, age estimates for gymnosperms and ferns, among other clades, have been compiled by Hedges and Kumar (2009).

We identified 242 corresponding nodes (Table 1 ). Of these nodes, 26 were identified by comparing gymnosperm and fern clades from Hedges and Kumar (2009) with R20120829.new. The other nodes represented correspondences between Bell et al. (2010) and R20120829. new. Node names lacking in the plain text archive of the megatree were added. This modified R20120829mod.new is available in the Supplementary Material*.

Age estimates of all 242 nodes are available as ages files from the authors (Table 1). Four groups of subsequent nodes within the same lineages were estimated to have identical ages by Bell et al. (2010). As shown in Table 2, we corrected the age estimates by + or -0.1 Myr to avoid distortion of the community tree.

Calibrating the modified version R20120829mod.new with provided ages files produces a phylogeny that differs substantially from the original file (R20120829.new) calibrated with the age estimates from Wikström et al. (2001), especially regarding gymnosperms and ferns (Figures 1 and 2), because these clades were previously not covered by the wikstrom.ages file. Important to note is that difference in trees results from varying divergence times, while tree topology is maintained. Such differences indicate that phylogenetic community analyses can generate relatively different results depending on the chosen databases, which can lead to ecological misinterpretation if based on incorrect data (Gastauer and Meira-Neto, 2013).

\footnotetext{
* Supplementary Material: http://www.leep.ufv.br/pt-BR/ noticia/pesquisadores-da-floresta-escola-lancam-artigocientifico-sobre-computacao-da-diversidade-filogenetica
} 
Table 1. Age estimates (ages $\exp ^{1}$ and ages $\operatorname{logn}^{2}$ ) of corresponding nodes between R20120829.new and vascular plant phylogenies provided by Hedges and Kumar (2009) as well as Bell et al. (2010) using syntax of R20120829mod.new and their comparison to former age estimates given by Wikström et al. (2001, wikstrom.ages). Nodes with age estimates according to Hedges and Kumar (2009) are marked with asterisks*.

\begin{tabular}{|c|c|c|c|}
\hline Node name & wikstrom. ages & ages_exp ${ }^{1}$ & ages $\log n^{2}$ \\
\hline euphyllophyte* & 400 & 466 & 466 \\
\hline monilophyte* & & 364 & 364 \\
\hline equisetales_to_polypodiales* & & 360 & 360 \\
\hline seedplants* & & 355 & 355 \\
\hline gymnosperms* & & 354 & 354 \\
\hline ginkgoaceae_to_gnetales* & & 346 & 346 \\
\hline osmundales_to_polypodiales* & & 323 & 323 \\
\hline ophioglossaceae_to_psilotaceae* & & 306 & 306 \\
\hline gnetales_to_pinales* & & 298 & 298 \\
\hline pinales $*$ & & 288 & 288 \\
\hline hymenophyllaceae to polypodiales* & & 286 & 286 \\
\hline cycadales* & & 283 & 283 \\
\hline lygopodiaceae_to_polypodiales* & & 266 & 266 \\
\hline gleicheniales* & & 263 & 263 \\
\hline araucariaceae to podocarpaceae* & & 257 & 257 \\
\hline taxaceae_to_cupressaceae* & & 227 & 227 \\
\hline marsileaceae to polypodiales* & & 220 & 220 \\
\hline schizaeales* & & 212 & 212 \\
\hline cyatheales_to_polypodiales* & & 211 & 211 \\
\hline cyatheales* & & 183 & 183 \\
\hline angiosperms & 179 & 147 & 183 \\
\hline polypodiales* & & 176 & 176 \\
\hline salviniales & & 173 & 173 \\
\hline austrobaileyales_to_asterales & 165 & 144 & 173 \\
\hline gnetales* & & 159 & 159 \\
\hline ceratophyllales_and_eudicots & & 129 & 156 \\
\hline dennstaedtiaceae to polypodiaceae* & & 151 & 151 \\
\hline magnoliales_to_asterales & 162 & 130.1 & 146 \\
\hline monocots & & 129.9 & 146 \\
\hline poales_to_asterales & 161 & 130 & 146 \\
\hline narthecidae & & 118 & 136 \\
\hline eudicots & 147 & 128.9 & 129 \\
\hline sabiales_to_asterales & 137 & 126 & 129 \\
\hline subrosid & 121 & 116.8 & 128 \\
\hline petrosaviidae & & 109 & 124 \\
\hline alismatales & 124 & 107 & 122 \\
\hline magnoliids & & 125 & 122 \\
\hline core_eudicots & 127 & 117 & 121 \\
\hline pentapetalids & & 116.9 & 120 \\
\hline subasterids & & 116.8 & 120 \\
\hline laurales & 111 & 112 & 119 \\
\hline piperales & 132 & 104 & 119 \\
\hline proteales & 135 & 110 & 116 \\
\hline rosids & & 108 & 116 \\
\hline malvids & 95 & 107 & 115 \\
\hline liliales & 96 & 86 & 114 \\
\hline asterids & & 104 & 110 \\
\hline ericales_to_asterales & 117 & 104 & 110 \\
\hline lamiids_to_campanulids & & 99 & 108 \\
\hline ranunculales & 140 & 100 & 108 \\
\hline fabids & 98 & 103 & 107 \\
\hline
\end{tabular}

\footnotetext{
${ }^{1}$ Exponential distribution of minimum age constraints from fossil data. ${ }^{2}$ Lognormal distribution.
} 
Table 1. Continued...

\begin{tabular}{|c|c|c|c|}
\hline Node name & wikstrom. ages & ages_exp ${ }^{1}$ & ages_logn 2 \\
\hline caryophyllales & 84 & 99 & 106 \\
\hline aristolochiaceae & 108 & 91 & 104 \\
\hline celastrales_to_malpighiales & & 101 & 104 \\
\hline lamiids & & 96 & 104 \\
\hline asparagales & 107 & 92 & 103 \\
\hline commelinids & & 96 & 103 \\
\hline saxifragales & 111 & 95 & 103 \\
\hline campanulids & 107 & 93 & 100 \\
\hline buxaceae & 97 & 98 & 99 \\
\hline nitrogenfixing & & 99 & 99 \\
\hline platanaceae_to_proteaceae & & 98 & 99 \\
\hline santalales & 69 & 91 & 99 \\
\hline calycanthaceae & 52 & 98 & 98 \\
\hline chloranthaceae & 132 & 121 & 98 \\
\hline fagales_to_cucurbitales & & 96 & 96 \\
\hline aspleniaceae_to_onocleaceae & & 95 & 95 \\
\hline drypteridaceae_to_polypodiaceae & & 94 & 94 \\
\hline geraniales & 92 & 87 & 93 \\
\hline oxalidales & 77 & 89 & 93 \\
\hline poales & 72 & 85 & 93 \\
\hline crossosomatales & 62 & 84 & 92 \\
\hline dioscoreales & 95 & 83 & 92 \\
\hline ericales & 100 & 92 & 92 \\
\hline malpighiales & 81 & 89 & 92 \\
\hline araceae & 98 & 79 & 89 \\
\hline austrobaileyales & & 89 & 89 \\
\hline myrtales & 88 & 89 & 89 \\
\hline sabiaceae & 129 & 87 & 89 \\
\hline papaveraceae & 112 & 82 & 88 \\
\hline aquifoliales & 97 & 88 & 87 \\
\hline cornales & 101 & 87 & 87 \\
\hline lardizabalaceae_to_circaeasteraceae & & 81 & 87 \\
\hline rosales & 76 & 82 & 85 \\
\hline asterales & 90 & 77 & 84 \\
\hline zingiberales & 62 & 84 & 84 \\
\hline fabales & 79 & 79 & 83 \\
\hline malvales & 68 & 78 & 83 \\
\hline brassicales & 79 & 83 & 82 \\
\hline pandanales & 88 & 72 & 82 \\
\hline achariaceae & & 79 & 81 \\
\hline canellales & 99 & 77 & 80 \\
\hline garryales & 93 & 70 & 77 \\
\hline celastrales & 42 & 71 & 76 \\
\hline commelinales & 68 & 70 & 76 \\
\hline magnoliales & 113 & 69 & 76 \\
\hline solanales & 78 & 71 & 76 \\
\hline lamiales & 63 & 69 & 74 \\
\hline linaceae & 33 & 71 & 73 \\
\hline escalloniaceae & & 65 & 72 \\
\hline ranunculaceae_to_berberidaceae & & 67 & 72 \\
\hline passifloraceae & 26 & 68 & 71 \\
\hline sapindales & 61 & 71 & 71 \\
\hline stylidiaceae & & 65 & 71 \\
\hline
\end{tabular}

${ }^{1}$ Exponential distribution of minimum age constraints from fossil data. ${ }^{2}$ Lognormal distribution. 
Table 1. Continued...

\begin{tabular}{|c|c|c|c|}
\hline Node name & wikstrom. ages & ages_exp ${ }^{1}$ & ages_logn \\
\hline gentianales & 71 & 65 & 69 \\
\hline cornaceae & 64 & 67 & 67 \\
\hline cucurbitales & 65 & 61 & 67 \\
\hline melanthiaceae & & 59 & 67 \\
\hline moringaceae_to_caricaceae & & 64 & 67 \\
\hline poaceae_to_flagellariaceae & & 58 & 65 \\
\hline bursa_to_anaca & 51 & 50 & 64 \\
\hline tofieldiaceae & & 61 & 64 \\
\hline fabaceae & 56 & 61 & 63 \\
\hline rhizophoraceae & & 60 & 63 \\
\hline salicaceae & 23 & 61 & 63 \\
\hline rhamnaceae & 55 & 59 & 62 \\
\hline solanaceae_to_convolvulaceae & & 59 & 62 \\
\hline cyperaceae_to_juncaceae & & 55 & 61 \\
\hline primulaceae & & 57 & 61 \\
\hline dipsacales & 81 & 57 & 60 \\
\hline malpighiaceae & 32 & 61 & 60 \\
\hline plumbaginaceae to polygonaceae & & 58 & 60 \\
\hline amaranthaceae to_caryophyllaceae & & 55 & 59 \\
\hline ranunculaceae & 65 & 55 & 59 \\
\hline dilleniaceae & 52 & 55 & 58 \\
\hline liliaceae & 48 & 52 & 58 \\
\hline boraginaceae & 59 & 54 & 57 \\
\hline celastraceae & 34 & 53 & 57 \\
\hline rubiaceae & 56 & 57 & 57 \\
\hline campanulaceae & 33 & 53 & 56 \\
\hline cannabaceae_to_moraceae & & 54 & 56 \\
\hline gesneriaceae & 38 & 52 & 56 \\
\hline fagales & 61 & 52 & 55 \\
\hline geraniaceae & 38 & 48 & 54 \\
\hline meliaceae_to_rutaceae & & 53 & 54 \\
\hline saururaceae & 75 & 47 & 54 \\
\hline styracaceae_to_diapensiaceae & & 51 & 54 \\
\hline apiales & 69 & 49 & 53 \\
\hline $\begin{array}{l}\text { argophyllaceae_to_- } \\
\text { alseuosmiaceae }\end{array}$ & & 49 & 53 \\
\hline scrophulariaceae & & 51 & 53 \\
\hline tecophilaeaceae & & 45 & 52 \\
\hline penthoraceae_to_haloragaceae & & 48 & 51 \\
\hline crassulaceae $^{--}$ & 41 & 47 & 50 \\
\hline lythraceae & 37 & 46 & 50 \\
\hline santalaceae & 37 & 43 & 50 \\
\hline ochnaceae & & 49 & 49 \\
\hline circaeasteraceae & 54 & 45 & 48 \\
\hline lecythidaceae & 65 & 46 & 48 \\
\hline orchidaceae & 26 & 42 & 48 \\
\hline vitaceae & 92 & 65 & 48 \\
\hline menyanthaceae & 51 & 44 & 47 \\
\hline plantaginaceae & & 42 & 46 \\
\hline polygalaceae & 28 & 44 & 46 \\
\hline helwingiaceae_to_aquifoliaceae & & 42 & 45 \\
\hline oleaceae & 47 & 41 & 45 \\
\hline asparagaceae & 27 & 42 & 44 \\
\hline
\end{tabular}

\footnotetext{
${ }^{1}$ Exponential distribution of minimum age constraints from fossil data. ${ }^{2}$ Lognormal distribution.
} 
Table 1. Continued...

\begin{tabular}{|c|c|c|c|}
\hline Node name & wikstrom. ages & ages_exp $^{1}$ & ages_logn 2 \\
\hline rosaceae & 47 & 40 & 44 \\
\hline asteraceae & 44 & 40 & 43 \\
\hline brassicaceae_to_cleomaceae & & 41 & 43 \\
\hline hydrangeaceae & 78 & 44 & 43 \\
\hline plumbaginaceae & 27 & 43 & 43 \\
\hline dasypogonaceae & & 38 & 42 \\
\hline elaeocarpaceae & 59 & 38 & 42 \\
\hline lentibulariaceae & & 37 & 42 \\
\hline nymphaeales & & 38 & 42 \\
\hline polygonaceae & 28 & 41 & 42 \\
\hline sapindaceae & 36 & 41 & 42 \\
\hline strelitziaceae_to_lowiaceae & & 40 & 42 \\
\hline acanthaceae & 31 & 38 & 41 \\
\hline dioncophyllaceae_to_ancistrocladaceae & & 37 & 41 \\
\hline monimiaceae & 71 & 35 & 41 \\
\hline lamiaceae & 23 & 38 & 40 \\
\hline piperaceae & 43 & 32 & 40 \\
\hline rutaceae & 39 & 40 & 40 \\
\hline amaranthaceae & 19 & 37 & 39 \\
\hline malvaceae & 34 & 66 & 39 \\
\hline lardizabalaceae & 77 & 35 & 38 \\
\hline meliaceae & 30 & 39 & 38 \\
\hline sarcolaenaceae_to_dipterocarpaceae & & 35 & 38 \\
\hline saxifragaceae & 51 & 38 & 38 \\
\hline solanaceae & 41 & 37 & 38 \\
\hline styracaceae & 45 & 36 & 38 \\
\hline cannabaceae & & 36 & 37 \\
\hline caprifoliaceae & 10 & 36 & 37 \\
\hline cyperaceae & 16 & 32 & 37 \\
\hline oxalidaceae & 43 & 34 & 37 \\
\hline berberidaceae & 44 & 33 & 36 \\
\hline magnoliaceae & 70 & 33 & 36 \\
\hline musaceae & 50 & 34 & 36 \\
\hline polemoniaceae & 35 & 32 & 36 \\
\hline proteaceae & 47 & 35 & 36 \\
\hline thymelaeaceae & 26 & 36 & 36 \\
\hline melianthaceae & & 34 & 35 \\
\hline menispermaceae & 53 & 33 & 35 \\
\hline moraceae & 23 & 33 & 35 \\
\hline urticaceae & 22 & 34 & 35 \\
\hline iridaceae & 32 & 31 & 34 \\
\hline adoxaceae & 57 & 31 & 33 \\
\hline arecaceae & 73 & 31 & 33 \\
\hline brassicaceae & 24 & 31 & 33 \\
\hline cyclanthaceae & 45 & 30 & 33 \\
\hline loasaceae & 67 & 31 & 33 \\
\hline amaryllidaceae & 28 & 30 & 32 \\
\hline apiaceae & 33 & 29 & 32 \\
\hline juglandaceae_to_myricaceae & & 29 & 32 \\
\hline philydraceae & & 29 & 32 \\
\hline fagaceae & 34 & 28 & 31 \\
\hline poaceae & 12 & 28 & 31 \\
\hline verbenaceae & 20 & 29 & 30 \\
\hline
\end{tabular}

${ }^{1}$ Exponential distribution of minimum age constraints from fossil data. ${ }^{2}$ Lognormal distribution. 
Table 1. Continued...

\begin{tabular}{|c|c|c|c|}
\hline Node name & wikstrom. ages & ages_exp $^{1}$ & ages_logn ${ }^{2}$ \\
\hline cunoniaceae & 42 & 27 & 29 \\
\hline hamamelidaceae & 104 & 25 & 27 \\
\hline crossosomataceae_to_stachyuraceae & & 24 & 26 \\
\hline annonaceae & 26 & 23 & 25 \\
\hline bignoniaceae & 38 & 25 & 25 \\
\hline convolvulaceae & 20 & 24 & 25 \\
\hline onagraceae & 20 & 23 & 25 \\
\hline strelitziaceae & 29 & 23 & 25 \\
\hline combretaceae & 27 & 21 & 24 \\
\hline haloragaceae & 17 & 23 & 24 \\
\hline apocynaceae & 18 & 21 & 23 \\
\hline cucurbitaceae & 20 & 21 & 23 \\
\hline nyctaginaceae & 13 & 22 & 23 \\
\hline cactaceae_to_portulaceae & & 21 & 22 \\
\hline bromeliaceae & 33 & 20 & 21 \\
\hline costaceae & 27 & 19 & 21 \\
\hline betulaceae & 19 & 18 & 20 \\
\hline elaeagnaceae & 13 & 20 & 20 \\
\hline trochodendraceae & 106 & 19 & 20 \\
\hline araliaceae & 26 & 18 & 19 \\
\hline winteraceae & 42 & 18 & 19 \\
\hline zingiberaceae & 10 & 18 & 19 \\
\hline marantaceae & 23 & 17 & 18 \\
\hline chrysobalanaceae & 8 & 16 & 17 \\
\hline ericaceae & 12 & 14 & 15 \\
\hline lauraceae & 34 & 12 & 13 \\
\hline limnanthaceae & 9 & 12 & 13 \\
\hline pittosporaceae & 14 & 11 & 12 \\
\hline myristicaceae & 23 & 12 & 11 \\
\hline canellaceae & 17 & 10 & 10 \\
\hline altingiaceae & 56 & 7 & 7 \\
\hline akaniaceae & 31 & 6 & 6 \\
\hline juglandaceae & 6 & 4 & 4 \\
\hline
\end{tabular}

${ }^{1}$ Exponential distribution of minimum age constraints from fossil data. ${ }^{2}$ Lognormal distribution.

Table 2. Subsequent nodes in R20120829mod.new with identical age estimates according to Bell et al. (2010) exponential distribution $\left(\mathrm{BEAST}^{\mathrm{a}}\right)$ or lognormal distribution $\left(\mathrm{BEAST}^{\mathrm{b}}\right)$ of minimum age constraints plus corrected diversification time in ages_exp and ages_logn (available from Supplementary Material*).

\begin{tabular}{|c|c|c|c|c|}
\hline Node name & $\begin{array}{l}\text { Bell's BEAST' } \\
\text { age estimate }\end{array}$ & $\begin{array}{c}\text { Corrected } \\
\text { version } \\
\text { (ages_exp) }\end{array}$ & $\begin{array}{l}\text { Bell's BEAST }^{\text {b }} \\
\text { age estimate }\end{array}$ & $\begin{array}{c}\text { Corrected } \\
\text { version } \\
\text { (ages_logn) }\end{array}$ \\
\hline magnoliales_to_asterales & 130.0 & 130.1 & 146 & 146.1 \\
\hline poales_to_asterales & 130.0 & & 146.0 & \\
\hline monocots & 130.0 & 129.9 & 146.0 & 145.9 \\
\hline caryophylales_and_eudicots & & & 156.0 & 145.9 \\
\hline caryophylales_and_eudicots & 129.0 & & 156.0 & 145.9 \\
\hline eudicots & 129.0 & 128.9 & 129.0 & \\
\hline core_eudicots & 117.0 & 117.1 & 121.0 & \\
\hline pentapetalids & 117.0 & & 120.0 & \\
\hline subasterids, subrosids & 117.0 & 116.9 & 120.0 & 119.9 \\
\hline asterids & & & 110.0 & \\
\hline ericales_to_asterales & & & 110.0 & 109.9 \\
\hline
\end{tabular}




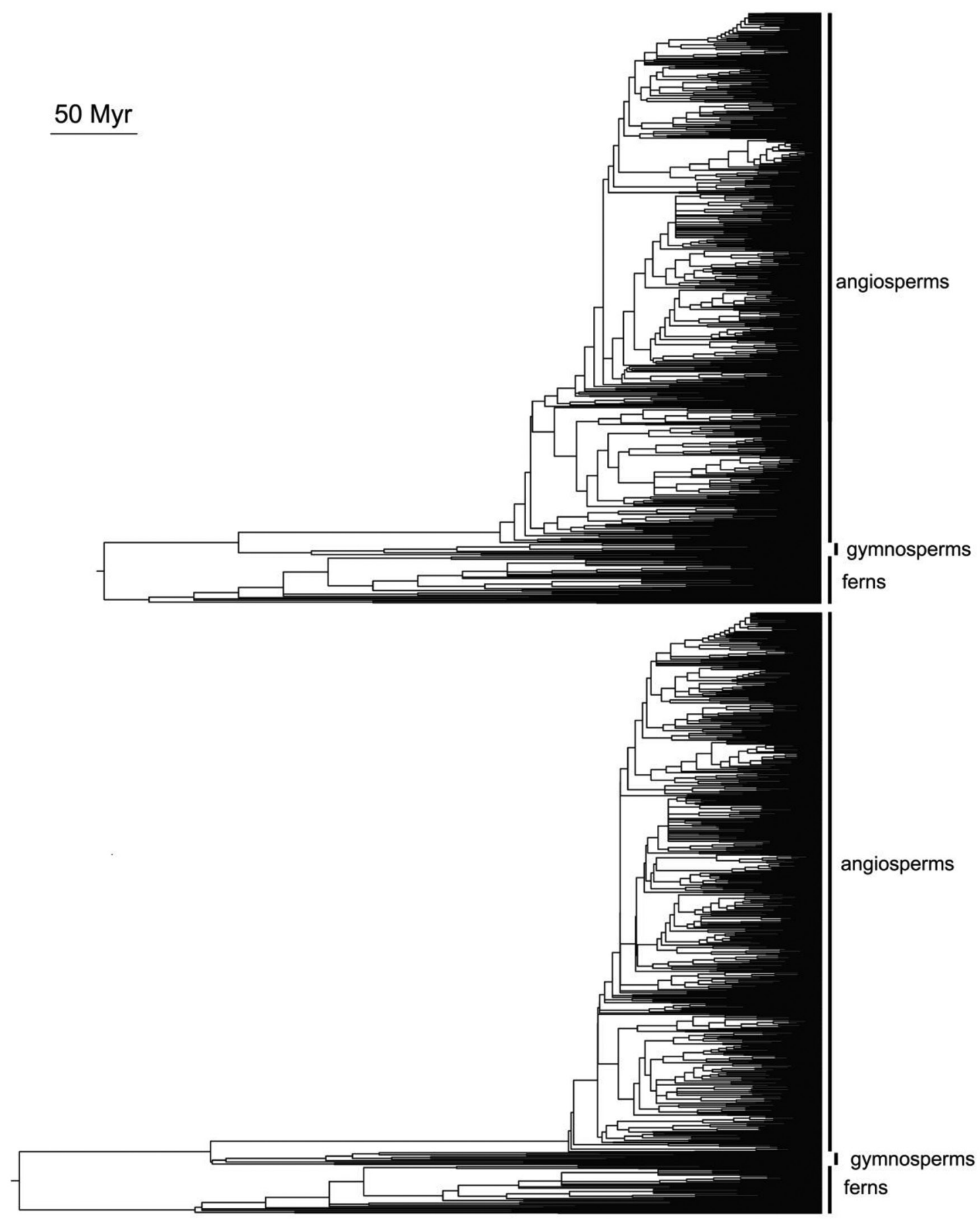

Figure 1. Hypothetical trees of a community composed of two species from all monophyletic families from APG III (APG III, 2009) that were inserted in the original megatree R20120829.new that was calibrated by agesclIII (see Gastauer and Meira-Neto, 2013 for details, upper tree) and R20120829mod.new calibrated by ages_exp (lower tree). 


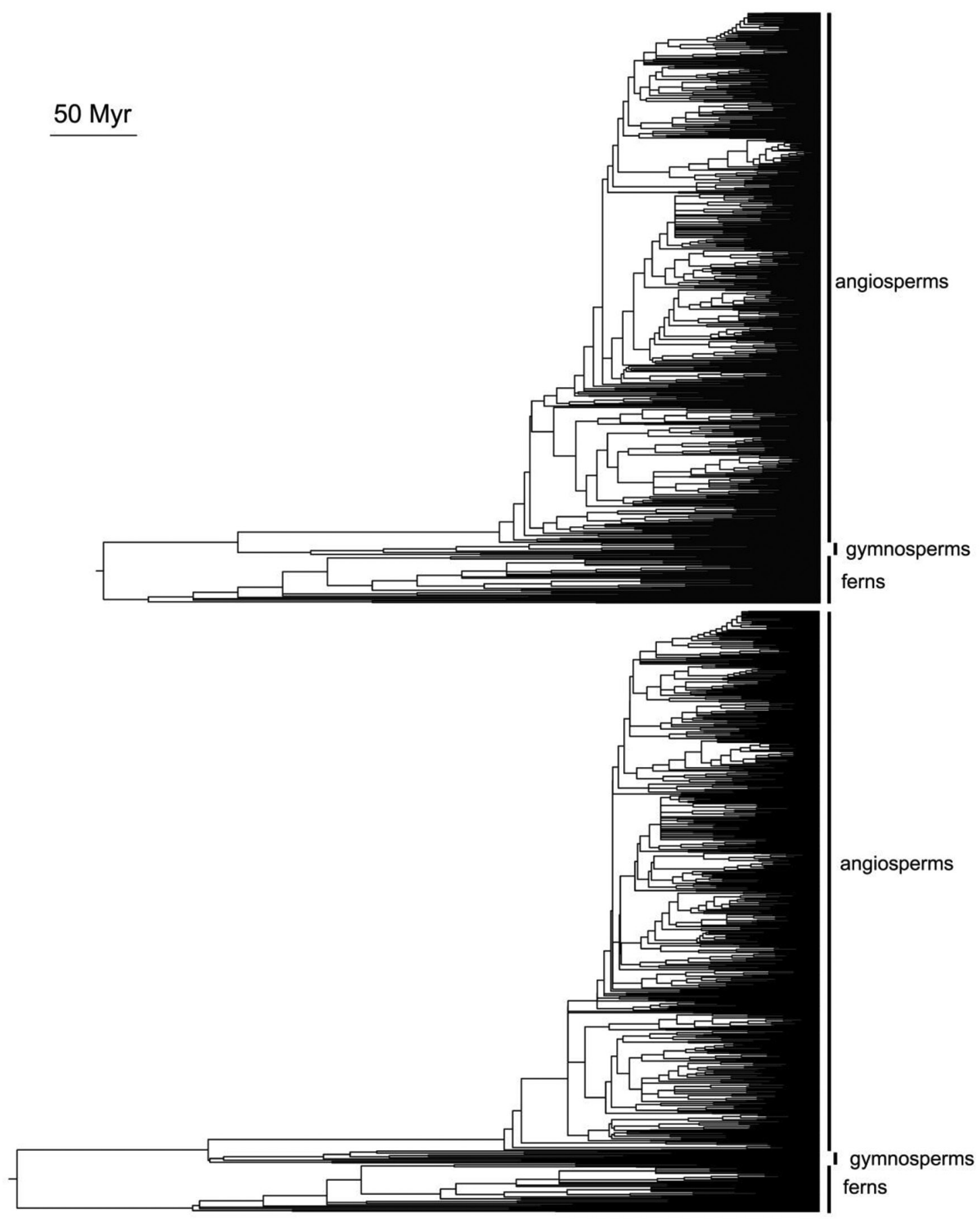

Figure 2. Hypothetical community trees containing two species of all monophyletic families from APG III (APG III, 2009) and resulting from insertion in the original megatree R20120829.new that was calibrated by agesclIII (see Gastauer and Meira-Neto, 2013 for details, upper tree) and R20120829mod.new calibrated by ages_logn (lower tree). 


\section{Conclusions}

Differences in tree branch calibrations may produce different results regarding phylogenetic diversity and/or change the ecological interpretation of measures of phylogenetic community structure. Our goal was to gather and make available the most updated vascular plant phylogeny as well as updated minimum divergence times, as available from the recent literature. For that, we recommend the consistent application of the R20120829mod.new file in combination with ages_exp or ages_logn (available in the Supplementary Material*). This ensures a more inclusive and updated calibration of phylogenetic trees including not only angiosperms, but also gymnosperms and ferns, due to a higher number of internal nodes being dated, distributed among the entire tree of euphyllophytes. Furthermore, users have the possibility to choose between underlying statistical extrapolation of age estimates in their studies of evolutionary ecology, phylogenetic comparisons and analysis of most recent common ancestor analysis in plants.

\section{Acknowledgements}

We are grateful to the Floresta-Escola Environmental Science Center, SECTES-MG, CNPq, FAPEMIG and CAPES for grants and scholarships.

\section{References}

ANGIOSPERM PHYLOGENY GROUP - APG III, 2009. An update of the Angiosperm Phylogeny Group classification for the orders and families of flowering plants: APG III. Botanical Journal of the Linnean Society, vol. 161, no. 2, pp. 105-121. http://dx.doi.org/10.1111/j.1095-8339.2009.00996.x.

BELL, C.D., SOLTIS, D.E. and SOLTIS, P.S., 2010. The age and diversification of the angiosperms re-revisited. American Journal of Botany, vol. 97, no. 8, pp. 1296-1303. http://dx.doi. org/10.3732/ajb.0900346. PMid:21616882.

FAITH, D.P., 1992. Conservation evaluation and phylogenetic diversity. Biological Conservation, vol. 61, no. 1, pp. 1-10. http:// dx.doi.org/10.1016/0006-3207(92)91201-3.

GASTAUER, M. and MEIRA-NETO, J.A.A., 2013. Avoiding inaccuracies in tree calibration and phylogenetic community analysis using Phylocom 4.2. Ecological Informatics, vol. 15, no. 1, pp. 85-90. http://dx.doi.org/10.1016/j.ecoinf.2013.03.005.
GASTAUER, M. and MEIRA-NETO, J.A.A., 2014. Interactions, environmental sorting and chance: phylostructure of a tropical forest assembly. Folia Geobotanica, vol. 49, no. 3, pp. 443-459. http://dx.doi.org/10.1007/s12224-013-9181-1.

GITHUB, 2014 [viewed 3 January 2014]. [online]. Available from: https://github.com/camwebb/tree-of-trees/tree/master/megatrees

HEDGES, S.B. and KUMAR, S., 2009. The time tree of life. New York: Oxford University Press.

LEMAIRE, B., HUYSMANS, S., SMETS, E. and MERCKX, V., 2011. Rate accelerations in nuclear $18 \mathrm{~S}$ rDNA of mycoheterotrophic and parasitic angiosperms. Journal of Plant Research, vol. 124, no. 5, pp. 561-576. http://dx.doi.org/10.1007/s10265-010-0395-5. PMid:21188459.

MAGALlÓN, S. and CASTILlO, A., 2009. Angiosperm diversification through time. American Journal of Botany, vol. 96, no. 1, pp. 349-365. http://dx.doi.org/10.3732/ajb.0800060. PMid:21628193.

MAGALLÓN, S., HILU, K.W. and QUANDT, D., 2013. Land plant evolutionary timeline: gene effects are secondary to fossil constraints in relaxed clock estimation of age and substitution rates. American Journal of Botany, vol. 100, no. 3, pp. 556-573. http://dx.doi.org/10.3732/ajb.1200416. PMid:23445823.

SMITH, S.A., BEAULIEU, J.M., STAMATAKIS, A. and DONOGHUE, M.J., 2011. Understanding Angiosperm diversification using small and large phylogenetic trees. American Journal of Botany, vol. 98, no. 3, pp. 404-414. http://dx.doi.org/10.3732/ ajb.1000481. PMid:21613134.

WEBB, C.O. and DONOGHUE, M.J., 2005. Phylomatic: tree assembly for applied phylogenetics. Molecular Ecology Notes, vol. 5, no. 1, pp. 181-183. http://dx.doi.org/10.1111/j.14718286.2004.00829.x.

WEBB, C.O., ACKERLY, D.D., MCPEEK, M.A. and DONOGHUE, M.J., 2002. Phylogenies and community ecology. Annual Review of Ecology and Systematics, vol. 33, no. 1, pp. 475-505. http:// dx.doi.org/10.1146/annurev.ecolsys.33.010802.150448.

WEBB, C.O., ACKERLY, D.D. and KEMBEL, S.W., 2008. Phylocom: software for the analysis of phylogenetic community structure and character evolution. Bioinformatics, vol. 24, no. 18, pp. 2098-2100. http://dx.doi.org/10.1093/bioinformatics/btn358. PMid: 18678590

WIKSTRÖM, N., SAVOLAINEN, V. and CHASE, M.W., 2001. Evolution of angiosperms: calibrating the family tree. Proceedings. Biological Sciences, vol. 268, no. 1482, pp. 2211-2220. http:// dx.doi.org/10.1098/rspb.2001.1782. PMid:11674868. 